\title{
Successes, Limitations, and Frontiers in Ecosystem Science: Reflections on the Seventh Cary Conference
}

\author{
Michael L. Pace* and Peter M. Groffman
}

Institute of Ecosystem Studies, Millbrook, New York, 12545, USA

The Seventh Cary Conference was held in May 1997 at the Institute of Ecosystem Studies in Millbrook, New York. The general mission of Cary Conferences is to examine fundamental issues in ecology. Previous conferences have considered diverse topics, including long-term studies (Likens 1989), comparative approaches (Cole and others 1991), humans as components of ecosystems (McDonnell and Pickett 1993), linking species and ecosystems (J ones and Lawton 1995), and the ecological basis for conservation (Pickett and others 1997). We organized the 1997 conference to assess the status of ecosystem science through analysis of notable successes, current limitations, and future frontiers.

Consider first success-what would you name as your five favorite developments in ecosystem science over the past twenty years? Would you focus on the enormous advances in computational and chemical methodologies, specific scientific results, compelling syntheses, or perhaps improved organization and infrastructure? We guess such a list would vary widely among ecosystem ecologists and, in part, this reflects lack of appreciation of successes in our discipline. For example, one success has been evaluation of the causes and consequences of eutro-

Received and accepted 8 October 1997

*Corresponding author. e-mail: 73753.2331@compuserve.com phication in fresh water [seethe chapter by Smith in Pace and Groffman (1998) ]. Theory and practice are richly endowed here, and clear predictions can be given for both general and specific questions about excess nutrient loading in a rivers, lakes, streams, and reservoirs covering a gamut of processes, including primary production, oxygen dynamics, and fish habitat utilization. Although the larger field of ecosystem science understands some of the progress in this area, it is not, in our view, widely trumpeted or even deeply appreciated.

Limitations - what holds us back in ecosystem research? Are we stymied by lack of theory, poor concepts, weak approaches, diffuse focus, fragmentation, technology, money, brains? Have we applied our science well? Are we working effectively with managers and fostering collaborations and institutions that facilitate learning about real world problems? How might we redress these limitations? The conference focused on these questions by considering limitations to intellectual progress and application of science.

As to the future - what are the major frontiers in ecosystem research? What are the key unknowns and how should we proceed? These are tough questions and even tougher to answer for a diverse science like ours. One might think such discussions would be the focus of our national meetings and 
frequent workshops, but those are given usually to the more specific, meaty science of the momentnot the roving, sometimes raving, discussionsneeded to pull science forward conceptually.

Below we summarize and comment on some, but certainly not all, of the interesting points raised at the conference. Table 1 provides a complete list of conference topics to be published in a forthcoming volume (Pace and Groffman 1998).

\section{Declaring Victory or Navel Gazing?}

Any collection of scientists charged to boast their successes is likely to be branded as acting either in rampant self-interest or excessive, self-conscious navel gazing. But self-interest is well served by thoughtful perspective (just gazing) on what went right and why. We can advance the discipline by understanding our successes, and in a science as diverse as ecosystem research, we need reminding. The conference considered several case histories, including topics ranging from riparian research (Richard Lowrance) to restoration (Jim MacMahon). Specific scientific accomplishments were noted. For example, Kathie Weathers summarized six general contributions of acid deposition research to advancing ecosystem ecology. This work (1) stretched our concept of ecosystem boundaries; (2) quantified inputs of rain, cloud, and dry deposition; (3) elucidated soil responses to sulfur, nitrogen, and trace metals; (4) documented widespread biological and chemical effects of acidification on fresh waters; (5) illuminated linkages among air pollution and terrestrial and aquatic ecosystems through analysis of connections between surface water, groundwater and soil processes; and (6) developed models of ecosystem response to air pollution. Similarly, Phil Robertson summarized significant contributions of agroecology to ecosystem science as falling in the general areas of soil organic matter dynamics, process-specific studies of the nitrogen cycle, and in the analysis of soil resource heterogeneity.

In addition to these specific examples of scientific advance, we were impressed by the diversity of paths that speakers chose to evaluate success. Some focused on science and the history of research topics, whereas others surveyed the interplay between science successes and human values and policy. Success was considered in two lightsadvances in basic understanding and advances in providing insights and possible solutionsto environmental problems. There has been differential success by this criteria. For example, many successes in the application of knowledge about forest ecosystems (Virginia Dale) and widespread alteration of biogeochemical cycles (Indy Burke) are waiting to happen rather than realized.

And what of the role of science in causing real change in the management, protection, and utilization of valuable ecosystems? Wetlands represent an interesting case. How did the perception of wetlands change from wastelands to sanctuaries? J oy Zedler argued that our changing values toward wetlands, while underwritten by research, were al so driven by key individuals in academic and government positions, popular writings by scientists, and unconfirmed or even incorrect scientific general ities. These forces propelled specific legislation for conservation and management. The popularization and changing perceptions of wetlands are seen in the history of articles in newspapers like the $\mathrm{N}$ ew York Times and Wall Street J ournal. Coverage has clearly increased and shifted in style. When the mood toward wetland protection was building, articles were typically pro-protection. Today, analysis is more sophisticated, and the average newspaper article is focused more on informing readers rather then taking either a pro or con position. This trend implies that a more difficult and honest job lies ahead for ecosystem science. We have an interested public audience. Research, however, has complexities. As these impinge on policy, the bar is raised higher for convincing anyone to take action or even what action to take. To avoid the paralysis of analysis, ecosystem scientists must learn to distill their findings and focus their arguments when addressing the public. The need for translating and popularizing science grows.

So what of our successes-should we declare victory? By all means-but the shortcomings of existing knowledge and challenges of application are also clearly recognized. There was no shyness among the speakersin saying there is plenty of work left to do.

\section{Human Values, Environmental Problems, and Other Angst}

Early discussions at the conference were in something of a tumult over the relations among science, successes, human values, and environmental problems. There are clear interactions between our success stories and environmental problems. The latter motivate a great deal of ecosystem research. But how should ecosystem science respond to societal problems? And how should we both personally and professionally respond to the many processes that degrade the environment? One answer emerging from discussion at the conference was that ecosystem science has at least two responsibilities. 
Table 1. Complete List of Titles and Authors for the Seventh Cary Conference, Successes, Limitations and Frontiers in Ecosystem Science

Title

Introduction: needs and concerns in ecosystem science

Cultural eutrophication of inland, estuarine, and coastal waters

Managing forests as ecosystems: a success story or a challenge ahead?

Wastelands to wetlands: links between habitat protection and ecosystem science

Riparian forest ecosystems as filters for nonpoint-source pollution

Ecological research in agricultural ecosystems: contributions to ecosystem science and to the management of agronomic resources

Progress in understanding biogeochemical cycles at regional to global scales

Acid deposition research and ecosystem science: synergistic successes

Empirical and theoretical ecology as a basis for restoration: an ecological success story

Limitations to intellectual progress in ecosystem science

Improving links between ecosystem scientists and managers

The need for large-scale experiments to assess and predict the response of ecosystems to perturbation

Ecosystem approaches to the management and allocation of critical resources

Ecosystems and problems of measurement at large spatial scales

Integration of ecophysiological and biogeochemical approaches to ecosystem dynamics

Simulation modeling in ecosystem science

Understanding effects of multiple stressors: ideas and challenges

Within-system element cycles, input-output budgets, and nutrient limitation

Species composition, species diversity, and ecosystem processes: understanding the impacts of gl obal change Synthesis: what kind of a discipline is this? Anyhow?
Authors

Michael L. Pace and Peter M. Groffman

Val H. Smith

Virginia H. Dale

J oy B. Zedler, M eghan Q. Fellows, and Sally Trnka

Richard Lowrance

G. Philip Robertson and Eldor A. Paul

Ingrid C. Burke, William K. Lauenroth, and Carol A. Wessman

Kathleen C. Weathers and Gary M. Lovett

J ames A. MacMahon

Gene E. Likens

Carl Walters

Stephen R. Carpenter

Carl Folke

Carol A. Wessman and Gregory P. Asner

Donald R. Zak and Kurt S. Pregitzer

William K. Lauenroth, Charles D. Canham, Karen A. Poiani, W. Michael Kemp, and Steven W. Running

Denise L. Breitburg, J ames W. Baxter, Colleen Hatfield, Robert W. Howarth, Clive G. J ones, Gary M. Lovett, and Cathleen Wigand

Peter M. Vitousek, Lars O. Hedin, Pamela A. Matson, J ames H. Fownes, and J ason Neff

David Tilman

Peter M. Groffman and Michael L. Pace
The first is to help humans understand what they can (and cannot) get from their ecosystems. This means mapping out the consequences of human activity for the preservation of vital ecosystem qualities such as fisheries, forest products, and clean water. The causes and connections between human action and ecosystem condition must be made explicit. The second need is for ecosystem scientists to influence by educating. We must build an appreciation for ecological systems among the public if we are to influence how these systems are to be utilized, valued, and conserved.

\section{No Simple Answers?}

In considering limitations, Gene Likens was blunt, "Maybe a major, if not overriding intellectual limitation is the false assumption or belief that there will be simple, all-inclusive answers." He went on to say that we must honestly face the awesome complexity of ecosystems and incorporate that complexity into our scientific endeavors.

This caused a stir. Doesn't elegant science require simplification? Wasn't the delineation of watersheds and analysis of stream-water chemistry as a 
indicator of activity and output of watersheds at Hubbard Brook the essence of simplification of a complex ecosystem (Likens and Bormann 1995)? The answers are yes and yes, but this doesn't mean complexity and simplification are opposite poles of a continuum. Complexity is an attribute of ecosystems. Simplification is a strategy of research. The key point might be that we will not find "allinclusive" answers. Instead, appropriate simplification strategies will lead to specific theories and solutions. Ecological understanding will build from the integration of these specific theories by the process of synthesis (Pickett and others 1994). By this means, complexity can be encompassed.

Likens noted that as one practical consequence of facing ecosystem complexity, we tend to work in teams. No one ever told us how. Likens raised a number of questions about how we function as research groups. For example, what is an optimum group size, how should groups be led, and what are the attributes of effective collaboration? These questions suggest that funders of science must be cognizant of the means of scientific interaction and various approaches to collaboration. Individual scientists must also find their comfort zone either within or without teams. Success in the future will depend, in part, on good research teams. These should be nurtured and recognized.

\section{MismetaPHORS AND MANAgement}

Ecosystem "health" has become a commonplace perspective. But is the metaphor apt? Carl Walters argued it actually harms interactions between managers and scientists. Thinking in terms of health encourages, in Walters' view, the search for cures"magic bullets." Although we certainly benefit from these in medicine, prescriptions for ecosystems often don't work. The medical metaphor goes awry in another way. We can define the disease state of an organism, based on infection, physiological condition, and other symptoms. There can be no such definition for ecosystems, which may have more or less desirable states but cannot be considered "sick." Yet, programs seek to restore ecosystem function to produce a "healthy" state.

Walters argued that management should not become dependent on technological or other quickfix approaches. This results in continued search and application of specific remedies (for example, fish stocking, pesticides, and water releases) when a more comprehensive and experimental approach is warranted. Management should instead seek possibility and flexibility. The role of scientists is to map out the spectrum of uncertainty for the managers so they can, as they must, make decisions.

Walters also raised a deeper and more controversial problem. Most ecosystem scientists engage in detailed mechanistic studies. These studies form the foundation and routine business of our science and are often justified as providing the understanding necessary for making management decisions and policy analyses. Although mechanistic, processoriented studies certainly deepen understanding, they may or may not contribute to either short-term or long-term management. This is Humpty-Dumpty's egg. It is simply not possible to put all the pieces together from detailed research to make management-oriented predictions, especially over the large landscapes and seascapes for which decisions must be made. It is clear that mechanistic research may contribute. It is a delusion that mechanistic research alone will solve management questions. Scientists shouldn't oversell the benefits of their investigations.

\section{FOOTPRINTS AND FINGERPRINTS}

Ecosystem frontiers were viewed from diverse perspectives, including millennial patterns of nutrient cycling (Peter Vitousek), satellite measurements (Carol Wessman), simulation modeling (Bill Lauenroth), and multiple stresses (Denise Breitburg). Ever present in the discussion of research futures were the impacts of humans and the challenges posed to understand these.

As a way of explicitly linking humans and ecosystems, Carl Folke described the concept of ecological footprints. These are the areal extent of ecosystem goods and services required to support a population. Folke cited an analysis of the 22 million city dwellers in the Baltic Sea drainage. This population requires a total appropriation of the natural resources and services of terrestrial and marine ecosystems that is 600-1200 times the combined area of the cities. That's $60,000-120,000 \mathrm{~m}^{2}$ per citizen. Those who minimize the dangers of rapid human population growth often comment that all the world's people would fit shoulder to shoulder into Texas. What they don't say is what these nouveauTexans would need to live. The ecological footprint makes the connection explicit. The current global population would need $6 \times 10^{14} \mathrm{~m}^{2}$ (roughly the area of the earth) to live like well-off Swedes, given today's technology and consumption.

Global human activity may have more subtle but equally far-reaching impacts on ecosystems. Here, the effects will be more like fingerprints. For example, rising atmospheric carbon dioxide may affect 
carbon allocation in plants, changing the distribution of carbon among leaves, shoots, and roots. Such changes in turn could have enormousimplications for nutrient cycling and carbon degradation in soils as mediated by roots and microorganisms. Don Zak outlined some alternate hypotheses about how plants might respond to large-scale environmental changes and focused on the demography of individual rootsas a means of exploring these questions. This example demonstrated the need to integrate the physiological ecology of organisms with ecosystem-level biogeochemical cycles. Such approaches have been long-term staples for ecosystem science and will be equally important in the future. Mysteries remain below ground, as well as in the microbial world. These will need solutions if we are to appreciate fully the current functioning and future responses of ecosystems.

\section{BIG}

Steve Carpenter described ecosystem science as a four-legged table. The legs represent major approaches: (1) theory providesintegration; (2) comparison provides spatial context and pattern; (3) longterm studies provide temporal context, trends, and surprises; and (4) experiments provide measures of responses to perturbations and tests of mechanisms. Although most ecosystem scientists use several of these approaches, deliberate experimental manipulations at large scales or "ecosystem experiments" are underutilized. Yet, some of the most visible successes in the discipline have come from ecosystem experiments, like logging watersheds or dumping iron in the sea. Why aren't ecosystem scientists routinely engaged in large-scale experiments? Why aren't ecosystem scientists thinking and acting big?

Carpenter outlined cultural, pragmatic, and conceptual barriers to experimentation. Academic culture does not easily incorporate large-scale, longterm experimental projects, especially those in remote sitesfar from the eyes of risk-adverse administrators. Pragmatically, there are precious few protected sites where these manipulations can be conducted and sustained. The conceptual barriers are related to difficulty in applying experimental treatments over large scales, lack of controls or references, and the problem of inference-statistical and otherwise.

But the rewards and opportunitiesfor "big" experimentation are too great for these barriers to become blockades. Walters suggested that one of the few ways to untangle multiple confounding effects on ecosystems is to conduct experimental comparisons based on deliberate manipulations of variables of management interest. This might mean purposefully, and even radically, altering a river's flow regime or the harvesting rate of a fishery. This will require fuller collaboration of scientists and managers. Carpenter cautioned that these creatures have different missions, and the interaction may need to be stabilized by an independent, keystone institution that keeps both to the bargain. The potential for collaboration with management activities is everywhere, but most of us are not actively seeking or fostering this new source of experiments. It is time to take bigger steps.

\section{Dreaming and Thinking}

Indy Burke reminded us of the seminal role of "dreamers and thinkers" in considering the issue of successes in the study of large-scale biogeochemical cycles. Without our modern tools, Arrhenius, Vernadsky, Hutchinson, Redfield, Jenny, and others laid down many of the conceptual and early empirical foundations that guided future research. These pioneers relied on a systems approach and a recognition that element mass balances could be applied with profit over scales as large as the biosphere. From this beginning, new tools and methods enable us to ask and answer new questions about global budgets, atmosphere-biosphere interactions, and regional impacts of land use on biogeochemical cycles. These are areas of rapid progress often driven by topical funding. Burke cautioned that while we should admire this progress we must remember our ancestors. Their style of scholarship and synthesis, and their ability to move beyond the immediate, needs imitation. We must allow for the scientific muse and provide ourselves time to listen to it.

\section{Passion}

Gene Likens questioned whether we are attracting "the best and the brightest" to our field. If not, the development of ecosystem science will be severely limited. We submit that to attract the best we must demonstrate compelling problems and a means to attack them. We have at least half of this equation solved-the problems of ecosystem science in particular and ecology in general are of utmost importance. Leaders and teachers in our field, must, therefore, envision and articulate the problems and pathways of solution. The best of graduate education does exactly that. One dilemma for current and future students of ecology, as Likens noted, is the need for both depth and breadth. Specialization and disciplinary focus enable sound scientific contributions. Breadth keeps specialization from being simply narrow. Our students must somehow have both. 
Ultimately, our science will be driven by individuals passionately determined to learn, to answer questions, and to educate others. Fascination with the natural world is the spark for that passion. In our everyday work, we must somehow hold this fascination within ourselves and seek to instill it in others.

\section{The Rising Tide}

Ecosystem scientists are worried. We feel the growing human burdens on the biosphere (Vitousek and others 1997). We sense a mismatch between scientific effort and the scope of our problems. We doubt our capacity to educate and reverse a terrifying momentum. How should we behave in this condition?

Timothy Wirth, the US Under Secretary of State for Global Affairs, suggested in his keynote address "that we are never going to get anywhere unless there is public understanding. .." Wirth specifically challenged the conference participants with regard to the issue of climate change-in his view, our most significant problem. Although many ecologists might quarrel with the priority, the need is well taken and general. Wirth urged that we must do a "better job of telling our stories" and forecasting the "impacts" of climate change.

The challenge is not just to educate well but also to build a better science. David Tilman noted that with regard to nature's general patterns we still lack "rigorous tests, tied to mechanistic theory, that allow us to distinguish among competing hypotheses and establish workable theory." There may be no simple answers, but ecology must strive to find the answers, whatever their shape, and become a predictive science. Tilman contended that one of the strongest attributes of global change (climate and otherwise) will be alterations in the composition and diversity of ecosystems. These alterations will interplay with ecosystem processes to determine the nature, in both meanings of the word, of the future.

Our conference emphasized ecosystems, but, as the preceding argument indicates, ecosystem sci- ence will be effective only by integration with the full discipline of ecology. We cannot contend with ecosystems in the absence of understanding the characteristics of organisms and the dynamics of populations and communities. The need for integrating the sometimes disparate subdisciplines of ecology isnot just a question of unity. It is a necessity for strengthening our scientific foundation to meet the rising tide of human accelerated environmental change.

\section{ACKNOWLEDGM ENTS}

Funds provided by the National Science Foundation, Department of Energy, National Aeronautical and Space Administration, and the Institute of Ecosystem Studies (IES) supported the Cary Conference. Comments by C. Canham improved this paper. We thank the staff of IES, especially Jan Mittan, for help with the conference.

\section{REFERENCES}

Cole J, Lovett G, Findlay S, editors. 1991. Comparative analyses of ecosystems: patterns, mechanisms and theories. New York: Springer-Verlag.

J ones CG, Lawton J H, editors. 1995. Linking species and ecosystems. New York: Chapman and Hall.

Likens GE, editor. 1989. Long-term studies in ecology: approaches and alternatives. New York: Springer-Verlag.

Likens GE, Bormann FH. 1995. Biogeochemistry of a forested ecosystem. 2nd ed. New York: Springer-Verlag.

McDonnell MJ, Pickett STA, editors. 1993. Humans as components of ecosystems. New York: Springer-Verlag.

Pace ML, Groffman PM, editors. 1998. Successes, limitations and frontiers in ecosystem science. New York: Springer-Verlag. In press.

Pickett STA, Kolasa J , J ones CJ . 1994. Ecological understanding. San Diego: Academic.

Pickett STA, Ostfeld RS, Shachak M, Likens GE, editors. 1997. The ecological basis of conservation: heterogeneity, ecosystems, and biodiversity. New York: Chapman and Hall.

Vitousek PM, Mooney HA, Lubchenco J, Melillo JM. 1997. Human domination of earth's ecosystems. Science 277:494504. 